\title{
Gölbaşı İlçesinin Açık Yeşil Alan Durumu ve Bazı Yeşil Alan Standartlarına Göre Değerlendirilmesi
}

\author{
Melike DOĞAN ${ }^{1 *}$, Volkan KÜÇÜK² \\ ORCID 1: 0000-0002-0095-2277 \\ ORCID 2: 0000-0002-8245-1686 \\ ${ }^{1}$ Süleyman Demirel Üniversitesi, Fen Bilimleri Enstitüsü, Peyzaj Mimarlığı Ana Bilim Dalı, 32262, Isparta, Türkiye. \\ ${ }^{2}$ Süleyman Demirel Üniversitesi, Mimarlık Fakültesi, Peyzaj Mimarlığı Bölümü, 32262, Isparta, Türkiye. \\ *e-mail:melikedoganpm@gmail.com
}

Öz

Açık yeşil alanlar fiziksel çevreyi oluşturan en önemli ögelerden bir tanesi olmasının yanı sıra sağlıklı, fonksiyonel, estetik çevreler yaratılmasında önemli bir rol üstlenirler. Son dönemlerdeki sanayileşme, hızla artan nüfus, çevre tahribatlarındaki artış gibi doğayı ve çevreyi olumsuz etkileyen etmenler, yeşil alanlara duyulan önemi arttırmıştır.

Bu araştırmanın amacı; Gölbaş Illçesi'nin açık yeşil alan durumunu ortaya koymak ve alanların standartlara uygunluğunu belirlemektir. Bu amaçla çalışma kapsamında Ankara ili Gölbaşı ilçesinin mevcut açık yeşil alan varlığı nicel olarak ortaya konulmuştur. Ayrıca aktif olarak kullanılan, mahalle düzeyindeki park alanları ve okul bahçelerinin standartlara uygunluğu incelenmiş, harita ve çizelgelerle ortaya konulmuştur. Çalışma sonucunda Gölbaşı Illçesinin kişi başına düşen net yeşil alan miktarı 38,6 $\mathrm{m}^{2} /$ kişi, aktif yeşil alan miktarı 11,0 $\mathrm{m}^{2} / \mathrm{kişi}$ olarak bulunmuştur. Park alanlarının, 37 mahallede yeşil alan standartlarını sağladığı, 15 mahallede standartların altında kaldığı ve 2 mahallede ise hiç park olmadığı görülmüştür. Okul bahçelerinin ise sadece 19 mahallede standartlara uygun olduğu, 7 mahallede standartların altında kaldığı ve 28 mahallede hiç okul alanı bulunmadı̆̆ı belirlenmiştir. Elde edilen sonuçlar doğrultusunda ileriye dönük öneriler getirilmeye çalışılmıştır.

Anahtar Kelimeler: Gölbaşı ilçesi, açık-yeşil alanlar, yeşil alan standartları.

\section{A Research on the Open-Green Area Sufficiency of Gölbaşı County of Ankara Province}

\begin{abstract}
Light green areas are one of the most important elements in the physical environment, as well as healthy, functional and aesthetic environments play an important role in the creation. The negative effects of nature and environment factors such as recent industrialization, rapidly increasing population, the increase in environmental damage, green areas have increased the importance.

The aim of this research is to reveal the open green area status of Gölbaşı district and to determine the suitability of the areas to the standards. For this purpose, the present open green area presence of Gölbaşı district of Ankara province was determined as quantitative. In addition, the appropriateness of the parks and school gardens at the neighborhood level, which is actively used, has been examined and presented with maps and charts. As a result of the study, while the net green area per capita of Gölbaşı district was 38,6 $\mathrm{m}^{2} /$ person, the active green area
\end{abstract}

Atıf: Doğan, M., Küçük, V. (2019). Gölbaşı İlçesinin Açık Yeşil Alan Durumu ve Bazı Yeşil Alan Standartlarına Göre Değerlendirilmesi Mimarlık Bilimleri ve Uygulamaları Dergisi (MBUD), 4 (2), 155-171.

DOI: $\underline{10.30785 / \mathrm{mbud} .592374}$ 
was found as $11,0 \mathrm{~m}^{2} /$ person. It has been observed that the park area provide green area standards in 37 neighborhoods, that they are below the standards in 15 neighborhood and that there are no park in 2 neighborhood. It has been determined that the school gardens are in compliance with the standards in only 19 neighborhood, that they are below the standards in 7 neighborhood and that there are no school areas in 28 neighborhood. In line with the results, forward-looking proposals have been made.

Keywords: Gölbaşı district, open green areas, green area standards.

\section{Giriş}

Bir kentin genel karakterini, mimari yapılar, açık-yeşil alanlar ve bunların birbirleriyle olan ilişkileri ve bütünlüğü tayin eder. Açık-yeşil alanlar, insan ile doğa arasındaki bozulan ilişkiyi dengelemede ve kentsel yaşam koşullarının iyileştirilmesinde önemli bir konuma sahiptir. Bu nedenle gelişmiş ülkelerde açık-yeşil alanların nitelik ve nicelikleri, medeniyetin ve yaşam kalitesinin bir göstergesi olarak kabul edilmektedir. Bu kapsamda pek çok gelişmiş ülke, insanların zihinsel ve fiziksel ihtiyaçlarını göz önünde bulundurarak insan yaşamı için uygun kent mekânı veya ekolojisini planlama ve oluşturma çabasına yönelmektedirler. (Gül ve Küçük, 2001)

Gölbaşı İlçesi'nin sahip olduğu sosyal, ekonomik, kültürel, ekolojik, doğal bütün özellikleri, hızla artan nüfusu, ilçeyi son dönemlerde öne çıkaran etmenler olmuştur. Ayrıca Mogan Gölü gibi oldukça büyük bir su yüzeyine ve Mogan Parkı gibi oldukça büyük bir rekreasyon alanına sahiptir. Bu özellikler ilçede bir çekim noktası oluşturmakta bu da ilçenin yeşil alan varlığının önemini arttırmaktadır.

Bu sebeple bu çalışmanın amacı; Gölbaşı IIlçesi'nin yeşil alan potansiyelini ortaya koymak, sahip olduğu park alanlarının ve okul bahçelerinin yeşil alan standartlarına uygunluğunu belirlemek ve bu doğrultuda çözüm önerileri getirmektir.

\subsection{Açık yeşil alan kavramı}

Çetiner (1979)'a göre yeşil alanların, kentsel yerleşmeler ve kent insanları üzerinde boş zamanları değerlendirme, ruhsal ve bedensel sağlık açısından ve estetik yönlerden birçok olumlu katkıları bulunmaktadır. Insanların, yeşil alanlara ihtiyacı, yeşil alanların psikolojik ve fiziksel faydaları, çeşitli gözlem ve araştırmalarla ortaya konmuştur (Döllük, 2005).

Aksoy (2001)'a göre toplumda yaşayan insanların yararlanmasına açık olan; parklar, çocuk oyun bahçeleri, spor alanları, dinlenme ile gezinti alanları, şehir içi ve çevresindeki korular, açık aktif yeşil alanlar olarak nitelendirilmektedir. Yapı adaları içerisinde kalan özel bahçeler, tarım alanları, meyve bahçeleri ve ticari amaçı koru ve fidanlıklar, ağaçlandırma alanları, mezarlık alanları, askeri alanlar, spor tesisleri, okul ve hastane bahçeleri, yol ve meydanlardaki güvenlik şerit ve refüjleri pasif yeşil alan kapsamındadır.

Pamay (1978)'ın yaptığı sınıflandırmaya göre açık yeşil alanlar, genel alanlar ve özel alanlar şeklinde iki ana gruba ayrılmaktadır (Çulha, 2013).

a. Genel Alanlar; Kent halkına, kamuya ait alanlar olup, halkın yararlanmasına açık alanlar olarak hizmet verirler. Bu alanların bir kısmından halkın tümü, diğer kısmından da halkın bazı kesimleri yararlanabilir.

b. Özel Alanlar; Çoğunlukla halkın tümüyle yararlanamadığı özel ve tüzel kişilere ve kuruluşlara ait alanlardır. Bu alanlardan özellikle, mülk sahipleri, kurum üyeleri veya kuruluş mensupları özel surette veya belirli şartlarda yararlanabilirler.

\subsection{Yeşil alan normları}

Açık yeşil alan standartları her bölge için farklılık gösterebilir. Her bölgenin özellikleri birbirinden farklıdır ve bu sebeple talepleri de değişkenlik gösterebilir.

Yeşil alan standardı, kişi başına düşen yeşil alanların $\mathrm{m}^{2}$ miktarı olarak, kent üstündeki yeşil doku barındıran alanların tümünün, kentin genel nüfusuna bölünmesi biçiminde ifade edilmektedir (Aksoy, 2014). 
Açık yeşil alan standartlarının belirlenmesinde alanı yeşil dokusunun büyüklüğü ve nüfus belirleyici etmenlerdir.

Açık ve yeşil alan standartlarının belirlenmesinde göz önünde bulundurulacak diğer bir etmen ise kente dair özelliklerin detaylı olarak araştırılmasıdır. Kent ölçeğinde yapılan araştırmalar sonucunda kente dair mevcut durum, bu durumun gelişme eğilimleri, kentin karakterine dair elde edilen veriler kentsel standartların oluşturulmasında, açık ve yeşil alanların kentteki homojen dağılımında bir basamak görevi görmektedir. Bununla birlikte kentin ekonomik yapısı, turizm potansiyeli, yerleşmelerinin gelişmişlik düzeyi ve sanayileşme durumu gibi özellikleri, kentteki açık yeşil alan ihtiyacında ve bu alanlara yüklenen fonksiyonda değişikliğe yol açmaktadır (Özcan, 2000).

Kentsel doku içerisinde yeşil alan standartlarının belirlenmesinde dikkate alınan ilkeler genel olarak şunlardır;

Gereksinimler: İhtiyaçlar yaş, gelir, eğitim ve mesleğin getirdiği düşünce ve örgütlenme ile yaşama alanı ve hareket olanaklarına göre değişir.

Nüfus: Rekreasyon amaçlı yeşil alan miktarı ve dağılımları daha çok insan sayısı ve onların yerleşme noktalarına bağlıdır. Bu nedenle nüfus, gereksinimlerin saptanmasında da rol oynayan önemli bir etmendir. Nüfus artıp yerleşmeler büyüdükçe yeşil alan standartları düşmekte ve yoğun yerleşme yelerinde öneri normlara erişmek oldukça güç olmaktadır.

Kentlerin karakteri: Kentin büyüklüğü, iklim özellikleri, bulunduğu konum, doğal ve kültürel özellikleri.

Kullanım yoğunluğu: Standartların oluşturulmasında düşünülmesi gereken başka bir durum ise yeşil alanların yoğunluğudur. Gezinti, eğlence, spor alanlarında yoğunlukları birbirinden farklıdır. Örneğin, bir eğlence parkı 75 -100 kişi / ha olması gerekirken, tenis 25-35 kişi / ha olması gerekmektedir. (Şahin ve Barış, 1998)

Aksoy (2001)'a göre ülkemizde yeşil alan standardı, 02.09.1999 tarihinde yayınlanan 23804 sayılı “İmar Planı Yapılması ve Değişikliklerine Ait Esaslara Dair Yönetmelikte Değişiklik Yapılması Hakkında Yönetmelik" ile kişi başına düşen yeşil alan standardı $10 \mathrm{~m}^{2}$ olarak belirlenmiştir. Bu yönetmeliğe göre, $1,5 \mathrm{~m}^{2} /$ kişi büyüklüğünde çocuk bahçesi, $2 \mathrm{~m}^{2} /$ kişi mahalle parkı ve $2 \mathrm{~m}^{2} /$ kişi spor alanı olmak üzere toplam 5,5 $\mathrm{m}^{2} /$ kişi ve kent ünitesi düzeyinde ise kişi başına $3,5 \mathrm{~m}^{2} /$ kişi büyüklüğünde kent parkı ve 1 $\mathrm{m}^{2} /$ kişi büyüklüğünde stadyum olmak üzere toplam $4,5 \mathrm{~m}^{2} /$ kişi yeşil alan öngörülmüştür.

\subsection{Açık - yeşil alanların fonksiyonları}

Açık yeşil alanların kent ve kentli üzerinde birçok olumlu etkisi vardır. Kent üzerinde ki baskıyı azaltırken, kentte yaşayan insanlara da dinlenmeleri, yorucu şehir şehir yaşamından bir nebze de olsa uzaklaşmaları için olanaklar sağlarlar. Açık yeşil alanların sosyal, ekolojik, ekonomik, estetik ve psikolojik birçok işlevi vardır. Rekreasyon için olanak sağlarlar, insanlara doğa ile iç içe olmaları için imkân verirler, insanların kendilerini ve birbirleri ile olan ilişkilerini geliştirmelerine yardımcı olurlar.

Pamay (1978)'a göre ise yeşil alan fonksiyonları aşağıdaki gibi sıralanabilir (Çelik, 2013):

- Açık yeşil alanlar, kentin fiziksel yapısı içinde stabiliteyi sağlamaktadırlar. Kent alanları içinde oluşturulmuş fonksiyon alanları (konut, ticari, vb.) arasında tampon görevi yaparlar.

- Kentteki nüfus ve yapı yoğunluğunu sınırlamakla beraber bu yoğunluğu azaltarak, şehirlerin yağ lekesi gibi çevreye doğru genişlemesini de kontrol altında tutarlar.

- Kent içindeki yüksek yapılar ile kaybedilmiş olan insan ölçeği kavramını yeniden kentte kazandırır.

- Doğayla bağını tamamen koparmış düzgün formlu yapıların sert karakterlerini kırarak daha yumuşak geçişlerin oluşmasını sağlarlar.

- Yeni yerleşme alanlarının oluşması için rezerv alanlar olarak görev yaparlar.

- Kentin fiziksel yapısı içinde, estetik görünüm sağlayarak şehrin kimliğini vurgularlar.

- Açık alanlar, kent içinde araç ve yayalar için; konut, ticaret, rekreasyon ve yol alanlarını ayırarak trafik güvenliğini sağlarlar.

- Yeşil kuşaklar ve perdeler gürültü ve tozu emerler. 
- Şehrin mikro kliması üzerindeki olumlu etkileriyle, insanların yaşam kalitelerini artırırlar.

\section{Materyal ve Yöntem}

\subsection{Materyal}

Araştırmanın ana materyalini Ankara ili Gölbaşı ilçesi oluşturmaktadır. Gölbaşı ilçesi Ankara iline bağı merkez bir ilçedir. Gölbaşı 1965 yılında Çankaya ilçesinden ayrılarak ilçe olmuştur. Yıllar içerisinde hızlı bir gelişim gösteren Gölbaşı ilçesinin Ankara iline olan uzaklığı yaklaşık 20 km'dir. Batısında Yenimahalle, Polatlı, doğusunda Bala, kuzeyinde Çankaya, güneyinde Haymana ilçeleri bulunur. 54 mahalleye sahip Gölbaşı ilçesi 1364 kilometrekare alanıyla Ankara'nın yüz ölçümü en büyük 8. ilçesidir. Gölbaşı ilçesi mahalleleri Şekil 1'de verilmiştir.

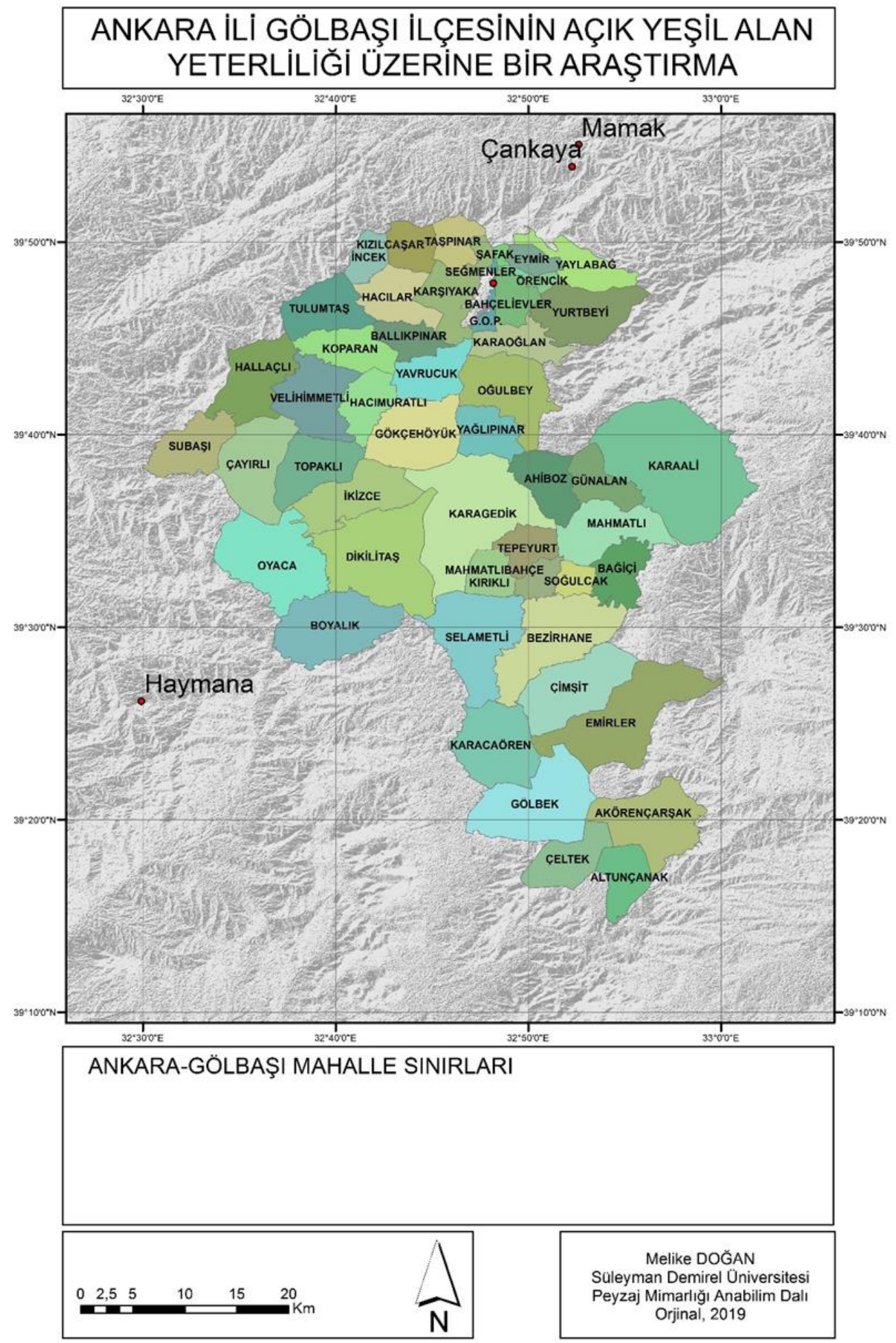

Şekil 1. Gölbaşı İlçesi Mahalleleri 


\subsection{Yöntem}

Araştırma kapsamında Gölbaşı ilçesi ile ilgili literatür taraması yapılmış, fotoğraf, belge ve raporların toplanmış, alanda gezi ve gözlem çalışmaları yapılmıştır. Elde edilen veriler, raporlar, planlar ve belediyeden alınan imar planından yararlanılarak ArcGis 10.2 programından yardım alınarak sayısallaştırılmış, harita ve tablolar halinde işlenmiştir. Çalışmanın akış diyagramı Şekil 2' de verilmiştir. Kişi başına düşen yeşil alan miktarı hesabı ise alanın yeşil alanlarının miktarı ile nüfusun oranlanması ile hesaplanmıştır.

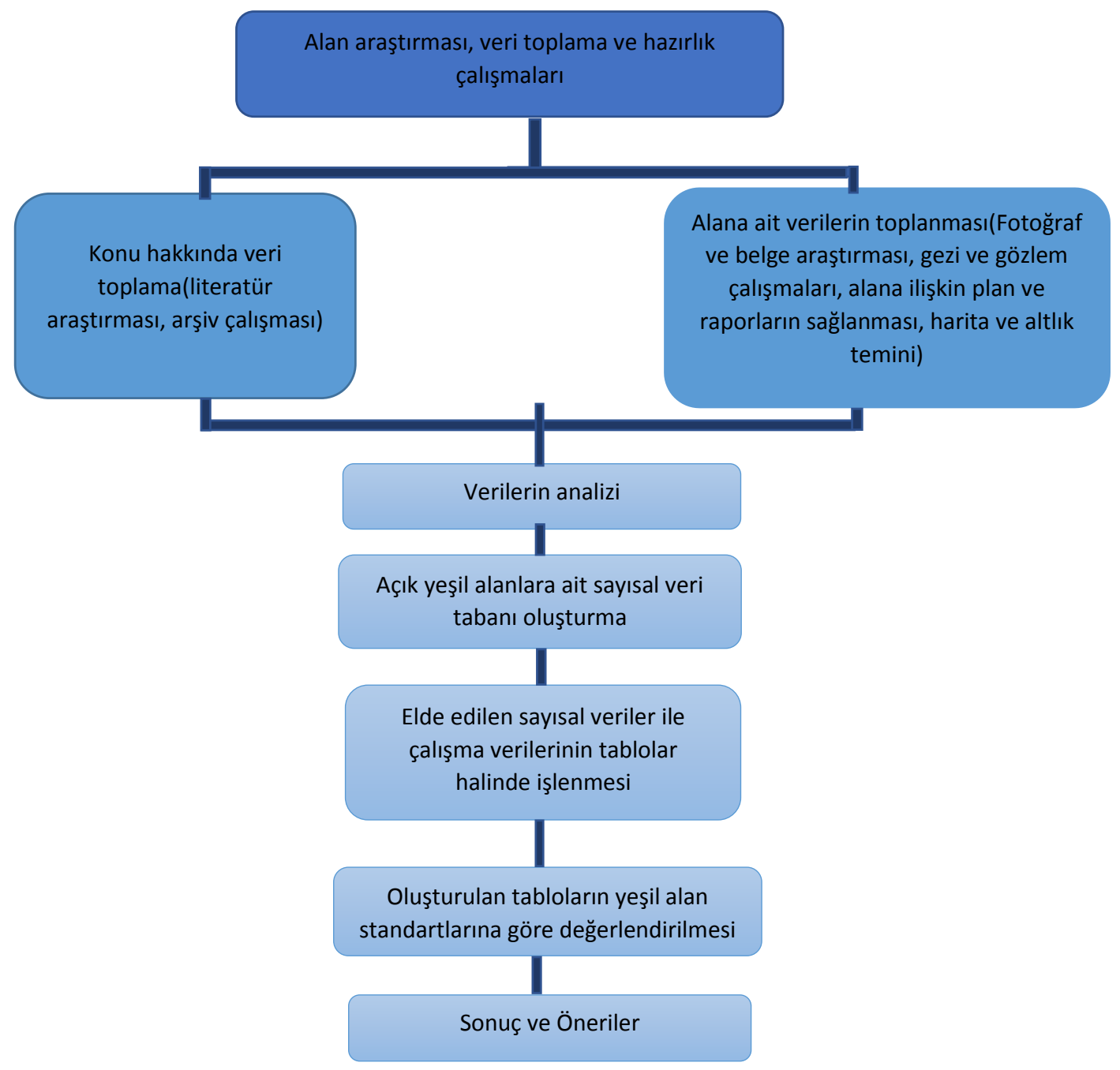

Şekil 2. Çalışma akış diyagramı

\section{Bulgular ve Tartışma}

\subsection{Gölbaşı ilçesinin demografik yapısı}

Nüfus Müdürlüğü ve TÜiK'den (Türkiye İstatistik Kurumu) alınan verilere göre Ankara ili Gölbaşı İlçesi 2018 yılı toplam nüfusu 134.378' dir. İlçenin 2007-2018 yılları arasındaki son 12 yıllık nüfus dalgalanması Şekil 3'te gösterilmiştir. 


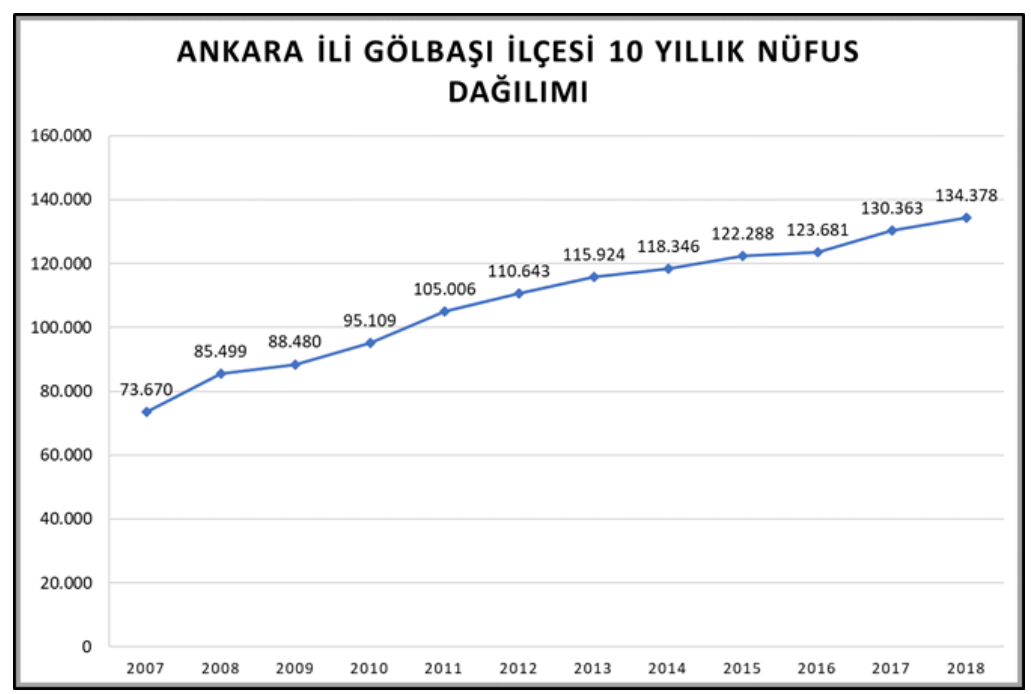

Şekil 3. Gölbaşı ilçesinin 12 yıllık nüfus grafiği

İlçenin 2018 yılı toplam erkek nüfusu 67.726, toplam kadın nüfusu 66.652'dir.

\subsection{Gölbaşı ilçesinin 2007-2017 yılları arasında ki açık yeşil alanlarının durumu}

\subsubsection{7 yılı açık yeşil alan durumu}

Gölbaşı Belediyesi 2007 Yılı Faaliyet Raporu'na göre 2007 yılı içerisinde bulunan (yol, refüj, ağaçlandırılmış alanlar, kamu hizmet bina bahçeleri, spor alanları vb.) park alanları dahil toplam açık yeşil alan miktarı $930.991 \mathrm{~m}^{2 \prime}$ dir. Kişi başına düşen net yeşil alan miktarı (park, çocuk oyun bahçesi, spor ve oyun alanı, hastane ve sağlık ocağı bahçesi, diğer kamu kurum ve tesis bahçesi, toplu konut ve lojman bahçesi, kavşak ve refüj, ağaçlandırma alanı, mezarlık, taşıt parkı, meyve bahçesi, meydan vb. tüm aktif-pasif yeşil alanlar dahil) 2007 yılında 73.670 nüfus göz önüne alınarak 12,63 m²/kişi 'dir. Aktif yeşil alan durumu incelendiğinde ise toplam aktif yeşil alan miktarı $890.991 \mathrm{~m}^{2}$ ve kişi başına düşen aktif yeşil alan miktarı 12,09 $\mathrm{m}^{2} /$ kişi olarak bulunmuştur.

\subsubsection{8 yılı açık yeşil alan durumu}

Gölbaşı Belediyesi 2008 yılı Faaliyet Raporu'na göre, yıl içerisinde toplam yeşil alan miktarı 1.269.588 $\mathrm{m}^{2 \prime}$ dir (Çizelge 1). Illçenin yılı nüfusu (85.499) da dikkate alındığında kişi başına düşen net yeşil alan miktarı (park, çocuk oyun bahçesi, spor ve oyun alanı, hastane ve sağlık ocağı bahçesi, diğer kamu kurum ve tesis bahçesi, toplu konut ve lojman bahçesi, kavşak ve refüj, ağaçlandırma alanı, mezarlık, taşıt parkı, meyve bahçesi, meydan vb. tüm aktif-pasif yeşil alanlar dahil) 14,84 $\mathrm{m}^{2} /$ kişi'dir. Aktif yeşil alan (parklar, oyun alanları, spor alanları, çocuk bahçeleri.) durumu incelendiğinde ise toplam aktif yeşil alan miktarııı $1.051 .588 \mathrm{~m}^{2}$ olduğu ve kişi başına düşen aktif yeşil alan miktarııı ise $12,29 \mathrm{~m}^{2} / \mathrm{kişi} \mathrm{ile}$ 2008 yılı için, Dünya standartlarında kentlerde kişi başına düşen ortalama yeşil alan miktarının $\left(10 \mathrm{~m}^{2}\right)$ üstüne çıktığı görülmüştür.

Çizelge 1. Gölbaşı ilçesi 2008 yılı yeşil alanları (Gölbaşı Belediye Başkanlığı, Park ve Bahçeler Genel Müdürlüğü,2008 Yıl Faaliyet Raporu'ndan faydalanılarak)

\begin{tabular}{|c|c|}
\hline 2008 YILI AÇIK YEŞiL ALAN DURUMU & YÜZÖLÇÜMÜ $\left(\mathrm{m}^{2}\right)$ \\
\hline Refüjler ve Ağaçlandırma Alanları & $218.000 \mathrm{~m}^{2}$ \\
\hline Mevcut Park ve Yeşil Alanlar & $956.411 \mathrm{~m}^{2}$ \\
\hline 2008 Yılı içerisinde Yapılan Park ve Yeşil Alanlar & $95.177 \mathrm{~m}^{2}$ \\
\hline TOPLAM & $1.269 .588 \mathrm{~m}^{2}$ \\
\hline
\end{tabular}

\subsubsection{9 yılı açık yeşil alan durumu}

Gölbaşı Belediyesi 2009 yılı Faaliyet Raporu'nda net açık yeşil alan miktarının $1.526 .825 \mathrm{~m}^{2 \prime}$ ye ulaştığı gözlenmiştir. 88.480 nüfusuyla kişi başına düşen net yeşil alan miktarı 2009 yılı için $17,25 \mathrm{~m}^{2} /$ kişi'dir. 


\subsubsection{Yılı açık yeşil alan durumu}

Toplamda ağaçlandırılmış yeşil alan miktarı $300.000 \mathrm{~m}^{2 \prime}$ dir. Yılsonunda ilçenin ulaştığı net açık yeşil alan miktarı $1.922 .663 \mathrm{~m}^{2}$ dir. 95.109 nüfusuyla 2010 yılında kişi başına düşen ortalama yeşil alan miktarı 20,21 m²/kişi'dir. 2010 yılı içerisinde $37.171 \mathrm{~m}^{2}$ yeni park alanı, $13.221 \mathrm{~m}^{2}$ mesire alanı yapılmıştır.

\subsubsection{Yılı açık yeşil alan durumu}

Gölbaşı Belediyesi Faaliyet Raporu'na göre 2011 yılı toplam nüfusu 105.006'dır. 2011 yılı içerisinde toplamda $18.500 \mathrm{~m}^{2} 5$ yeni park alanı yapılmış, 14.550 adet ağaç, 199.800 adet çiçek dikilmiştir.

Toplamda ilçede refüj alanı, ağaçlandırma alanı, mezarlık yeşil alanları, dinlenme ve çocuk parkırekreasyon alanı dahil $2.264 .520 \mathrm{~m}^{2}$ açık yeşil alan bulunmaktadır. Bu miktarla kişi başına düşen ortalama yeşil alan miktarı $21,56 \mathrm{~m}^{2} /$ kişi' dir.

\subsubsection{2 yılı açık yeşil alan durumu}

İlçenin 2012 nüfusu (110.642) göz önüne alındığında kişi başına düşen ortalama net toplam yeşil alan miktarının 22,30 m²/kişi olduğu görülmüştür. Ancak toplam açık yeşil alan miktarı $2.467 .929 \mathrm{~m}^{2}$ iken, aktif yeşil alan miktarı $1.107 .078 \mathrm{~m}^{2}$ olarak hesaplanmıştır. Kişi başına düşen ortalama aktif yeşil alan miktarına bakıldığında ise $10,00 \mathrm{~m}^{2} /$ kişi olduğu belirlenmiştir. Bu oranla Gölbaşı ilçesinin "Plan Yapımına Ait Esaslara Dair Yönetmelik" te yer alan kişi başına düşen ortalama yeşil alan miktarına $\left(10 \mathrm{~m}^{2} /\right.$ kişi) uygun olduğu görülmüştür (Çizelge 2$)$.

Çizelge 2. 2012 Yılı Açık Yeşil Alanları (Gölbaşı Belediye Başkanlığı, Park ve Bahçeler Genel Müdürlüğü, 2012 Yılı Faaliyet Raporu'ndan faydalanılarak)

\begin{tabular}{|l|r|}
\hline 2012 YILI AÇIK YEŞiL ALAN DURUMU & YÜZÖLÇÜMÜ $\left(\mathbf{m}^{\mathbf{2}}\right)$ \\
\hline 2012 Yılında Yeni Kazandırılan Ağaçlandırma Alanları & 116.550 \\
\hline Mevcut Ağaçlandırma Alanları & 500.000 \\
\hline 2012 Yılında Yeni Yapılan Park ve Yeşil Alanlar & 16.350 \\
\hline Mevcut Park ve Yeşil Alanlar & 1.078 .328 \\
\hline Meyve Bahçesi & 35.000 \\
\hline Sevgi Çiçeği Yetiştirme Alanı & 8.300 \\
\hline Belde Yeşil Alanları-Toplu Konut Bahçeleri & 465.034 \\
\hline Refüjler & 248.367 \\
\hline TOPLAM & $\mathbf{2 . 4 6 7 . 9 2 9}$ \\
\hline
\end{tabular}

\subsubsection{Yılı açık yeşil alan durumu}

2013 yılı içerisinde; $50.000 \mathrm{~m}^{2}$ ağaçlandırma alanı, $52.070 \mathrm{~m}^{2}$ park alanı, $68.343 \mathrm{~m}^{2}$ yeni yeşil alan oluşturulmuştur. $248.367 \mathrm{~m}^{2}$ refüj alanı, $616.550 \mathrm{~m}^{2}$ ağaçlandırma alanı, $35.000 \mathrm{~m}^{2}$ meyve bahçesi ve $8300 \mathrm{~m}^{2}$ sevgi çiçeği yetiştirme alanı ve yıl içerisinde kazandırılan $170.413 \mathrm{~m}^{2}$ yeni yeşil alan ile toplam yeşil alan miktarı $2.631 .692 \mathrm{~m}^{2 \prime}$ ye ulaşmıştır (Çizelge 3 ).

Çizelge 3. 2013 yılı açık yeşil alanları (Gölbaşı Belediye Başkanlığı Park ve Bahçeler Genel Müdürlüğü,2013 Yılı Faaliyet Raporu'ndan faydalanılarak)

\begin{tabular}{|c|c|}
\hline 2013 YILI AÇIK YEŞiL ALAN DURUMU & YÜZÖLÇÜMÜ $\left(\mathrm{m}^{2}\right)$ \\
\hline 2013 Yılında Yeni Kazandırılan Ağaçlandırma Alanları & 50.000 \\
\hline Mevcut Ağaçlandırma Alanları & 616.550 \\
\hline 2013 Yılında Yeni Yapılan Park ve Yeşil Alanlar & 120.413 \\
\hline Mevcut Park ve Yeşil Alanlar & 1.088 .028 \\
\hline Meyve Bahçesi & 35.000 \\
\hline Sevgi Çiçeği Yetiştirme Alanı & 8.300 \\
\hline Belde Yeşil Alanları-Toplu Konut Bahçeleri & 465.034 \\
\hline Refüjler & 248.367 \\
\hline TOPLAM & 2.631 .692 \\
\hline
\end{tabular}

2013 yılı nüfusu göz önüne alındığında kişi başına düşen ortama net yeşil alan miktarının 22,70 m²/kişi olduğu görülmüştür. Aktif açık yeşil alan miktarı ise toplam $1.107 .078 \mathrm{~m}^{2}$ iken kişi başına düşen miktarı $9,55 \mathrm{~m}^{2} /$ kişi olarak hesaplanmıştır. 


\subsubsection{Yılı açık yeşil alan durumu}

2014 yılı içerisinde $6550 \mathrm{~m}^{2}$ yeni park alanı $4815 \mathrm{~m}^{2}$ revize park alanı yapılmış ve 383.737 adet çiçek dikilmiştir. $66.550 \mathrm{~m}^{2}$ ise yeni yeşil alan ilçeye kazandırılmış toplam açık yeşil alan miktarı 2.698 .222 $\mathrm{m}^{2 \prime}$ ye ulaşmıştır. Bu yeşil alanlar ile kişi başına düşen net açık yeşil alan miktarı yaklaşık $22,79 \mathrm{~m}^{2} /$ kişi olarak hesaplanmıştır. Aktif açık yeşil alan (parklar, oyun alanları, spor alanları, çocuk bahçeleri vs) miktarına bakıldığında ise $1.113 .628 \mathrm{~m}^{2}$ iken kişi başına düşen açık yeşil alanın $9,40 \mathrm{~m}^{2} /$ kişi olduğu görülmüştür.

\subsubsection{Yılı açık yeşil alan durumu}

2015 yılı toplam yeşil alan miktarı $2.724 .022 \mathrm{~m}^{2 \prime}$ ye ulaşmıştır. Bu alanın $500.771 \mathrm{~m}^{2 \prime}$ sini ağaçlandırma alanı, $52.563 \mathrm{~m}^{2 \prime}$ sini kamusal yeşil alanlar, $248.367 \mathrm{~m}^{2 \prime}$ sini refüj alanları, $45.000 \mathrm{~m}^{2 \prime}$ sini meyve bahçesi, $8300 \mathrm{~m}^{2 \prime}$ sini sevgi çiçeği yetiştirme alanı, $18.300 \mathrm{~m}^{2 \prime}$ sini toplu konut bahçeleri, $25.800 \mathrm{~m}^{2 \prime}$ sini yeni yapılan yeşil alanlar, geri kalanını ise park alanları, çocuk bahçeleri, oyun alanları oluşturur.

Gölbaşı ilçesinde 2015 yılı kişi başına düşen yeşil alan miktarına bakıldığında Dünya standartlarının üzerinde bir yeşil alana sahip olduğu görülmüştür. 2015 yılı nüfusu 122.288 ve toplam yeşil alan miktarı $2.724 .022 \mathrm{~m}^{2}$ olduğu göz önüne alınarak hesaplandığında kişi başına düşen ortalama net yeşil alan miktarı(park, çocuk oyun bahçesi, spor ve oyun alanı, hastane ve sağlık ocağı bahçesi, diğer kamu kurum ve tesis bahçesi, toplu konut ve lojman bahçesi, kavşak ve refüj, ağaçlandırma alanı, mezarlık, taşıt parkı, meyve bahçesi, meydan vb. tüm aktif-pasif yeşil alanlar dahil) $22,27 \mathrm{~m}^{2} /$ kişi olarak bulunmuştur. Aktif yeşil alanlarının durumuna bakıldığında ise toplam $1.139 .428 \mathrm{~m}^{2}$ olduğu görülmüştür. Kişi başına düşen aktif yeşil alan miktarı ise $9,31 \mathrm{~m}^{2} /$ kişi ile yeşil alan standardının altında kalmıştır.

\subsubsection{Yılı açık yeşil alan durumu}

Gölbaşı Belediyesi Faaliyet Raporu'na göre Gölbaşı ilçesi $248.367 \mathrm{~m}^{2}$ refüj alanı, $616.320 \mathrm{~m}^{2}$ Mogan Parkı, $592.733 \mathrm{~m}^{2}$ mahallelerde bulunan yeşil alanlara sahiptir. Yıl içerisinde Gölbaşı ilçesi'ne kazandırılan $25.000 \mathrm{~m}^{2}$ yeni açık yeşil alan ile 2016 yılındaki toplam açık yeşil alan miktarının 2.729 .072 $\mathrm{m}^{2}$ olduğu görülmüştür (Çizelge 4). 2016 nüfusuyla oranlandığında kişi başına düşen ortalama net yeşil alan miktarı(park, çocuk oyun bahçesi, spor ve oyun alanı, hastane ve sağlık ocağı bahçesi, diğer kamu kurum ve tesis bahçesi, toplu konut ve lojman bahçesi, kavşak ve refüj, ağaçlandırma alanı, mezarlık, taşıt parkı, meyve bahçesi, meydan vb.. tüm aktif-pasif yeşil alanlar dahil) $22,06 \mathrm{~m}^{2} /$ kişi olarak hesaplanmıştır. (Tablolar Gölbaşı Belediye Başkanlığı, Park ve Bahçeler Genel Müdürlüğü Faaliyet Raporu'ndan faydalanılarak oluşturulmuştur.) Aktif yeşil alanlarının durumu incelendiğinde ise toplam aktif yeşil alan miktarının $1.271 .338 \mathrm{~m}^{2}$ olduğu, kişi başına düşen aktif yeşil alan miktarının ise 10,27 $\mathrm{m}^{2} /$ kişi ' ye ulaştığı görülmüştür.

Çizelge 4. Gölbaşı ilçesi 2016 Yılı Açık Yeşil Alanları (Gölbaşı Belediye Başkanlığı, Park ve Bahçeler Genel

Müdürlüğü, 2016 Yılı Faaliyet Raporu'ndan faydalanılarak)

\begin{tabular}{|l|r|}
\hline 2016 YILI YEŞiL ALAN DURUMU & YÜZÖLÇÜMÜ(m² \\
\hline Mevcut Ağaçlandırma Alanları & 500.771 \\
\hline 2016 Yılında Yeni Yapılan Park ve Yeşil Alanlar & 25.000 \\
\hline Mevcut Park-Yeşil Alanlar & 1.227 .288 \\
\hline Refüjler & 248.367 \\
\hline Sevgi Çiçeği Yetiştirme Alanı & 8.300 \\
\hline Meyve Bahçesi & 45.000 \\
\hline Mezarlık Yeşil Alanları-Kamusal Yeşil Alanlar & 53.313 \\
\hline Belde Yeşil Alanları-Toplu Konut Bahçeleri & 621.033 \\
\hline TOPLAM & $\mathbf{2 . 7 2 9 . 0 7 2}$ \\
\hline
\end{tabular}

\subsubsection{Yılı açık yeşil alan durumu}

2017 Yılı Faaliyet Raporu'na göre ağaçlandırma alanının bir önceki yıla göre $154.050 \mathrm{~m}^{2}$ azaltılarak $346.721 \mathrm{~m}^{2}$ olduğu görülmüştür. Yıl içerisinde toplamda $5050 \mathrm{~m}^{2}$ olmak üzere 2 adet park yapılmıştır. 2017 yılında ilçeye kazandırılan açık yeşil alanların toplam miktarı ise $127.500 \mathrm{~m}^{2 \prime}$ dir. Yeni kazandırılan yeşil alanlar ile birlikte Gölbaşı ilçesi yeşil alan miktarı 3.728.382 $\mathrm{m}^{2 \prime}$ ye ulaşmıştır. (Çizelge 5) Bu yeşil 
alanlar içerisinde $618.320 \mathrm{~m}^{2}$ Mogan Parkı, $248.367 \mathrm{~m}^{2}$ refüj alanı, $617.011 \mathrm{~m}^{2}$ mezarlık rekreasyon alanı ve $592.733 \mathrm{~m}^{2}$ mahalle yeşil alanları (imarda park alanı olarak ayrılmış alanlar) bulunmaktadır. Nüfus göz önüne alındığında kişi başına düşen ortalama net yeşil alan miktarının $28,60 \mathrm{~m}^{2} / \mathrm{kişi} \mathrm{olduğu}$ hesaplanmıştır. Yeşil alan standartlarına göre değerlendirildiğinde ise toplam aktif yeşil alan (parklar, oyun alanları, çocuk bahçeleri) miktarının $1.441 .624 \mathrm{~m}^{2}$ olduğu, kişi başına düşen ortalama aktif yeşil alan miktarının ise 11,05 m²/kişi olduğu belirlenmiştir. 02.09.1999 tarihinde yayınlanan 23804 sayılı "İmar Planı Yapılması ve Değişikliklerine Ait Esaslara Dair Yönetmelik" te kişi başına düşen aktif yeşil alan miktarının $10 \mathrm{~m}^{2} /$ kişi olduğu göz önüne alınırsa bu oranla standartların üzerine çıktığı görülmüştür.

Çizelge 5. Gölbaşı ilçesi 2017 yılı açık yeşil alanları (Gölbaşı Belediye Başkanlığı, Park ve Bahçeler Genel Müdürlüğü, 2017 Yılı Faaliyet Raporu'ndan faydalanılarak)

\begin{tabular}{|c|c|}
\hline 2017 YILI YEŞIL ALAN DURUMU & YÜZÖLÇÜMÜ(m²) \\
\hline Ağaçlandırma Alanları & 346.721 \\
\hline 2017 Yılında Yapılan Park-Yeşil Alanlar & 127.500 \\
\hline Mevcut Park-Yeşil Alanlar & 1.384 .011 \\
\hline Refüjler & 248.367 \\
\hline Sevgi Çiçeği Yetiştirme Alanı & 8.017 \\
\hline Meyve Bahçesi & 45.000 \\
\hline Mezarlık Yeşil Alanları & 617.011 \\
\hline Kamusal Alan Bahçeleri & 52.563 \\
\hline Belde Yeşil Alanları-Toplu Konut Bahçeleri & 618.757 \\
\hline Diğer Mühtelif Parklar-Yan Bant & 280.435 \\
\hline TOPLAM & 3.728.382 \\
\hline
\end{tabular}

\subsection{Gölbaşı ilçesinin mevcut açık yeşil alanları (2018)}

Bu bölümde 2018 yılı içerisinde; toplam açık yeşil alan ve aktif yeşil alan miktarı ortaya konmuş, kişi başına düşen yeşil alan miktarı hesaplanmıştır. Ayrıca kişi başına düşen park alanı ve okul bahçesinin, yeşil alan standartları göz önüne alınarak, yeşil alan yeterliliği araştııılmıştır. Gölbaşı ilçesinin tamamında kişi başına düşen park alanı miktarı ve Gölbaşı Illçe Milli Eğitim Müdürlüğü’nden alınan verilere göre; 54 mahallede kişi başına düşen okul bahçesi yeşil alan miktarı $\mathrm{m}^{2} /$ kişi hesabı ile ortaya konmuştur.

Gölbaşı ilçesinin mevcut açık yeşil alan durumu araştırıldığında; toplam net açık yeşil alan miktarının 5.185.231 $\mathrm{m}^{2}$ olduğu belirlenmiştir (Çizelge 6) (Şekil 4). Bu açık yeşil alan miktarının dağıımı incelendiğinde; $52.563 \mathrm{~m}^{2}$ kamusal alanlara (kamu hizmet binaları, camiler, muhtarlıklar) ait yeşil alana, $248.367 \mathrm{~m}^{2}$ refüj yeşil alanına, $617.011 \mathrm{~m}^{2}$ mezarlık alanına, 370,921 $\mathrm{m}^{2}$ ağaçlandırma alanına, 45.000 $\mathrm{m}^{2}$ meyve bahçesi alanına, $110.982 \mathrm{~m}^{2}$ Sevgi Çiçeği yetiştirme alanına, $868.660 \mathrm{~m}^{2}$ belde yeşil alanlarına-muhtelif parklara ve $28.824 \mathrm{~m}^{2}$ belediye bünyesine bağlı toplu konut bahçesine sahip olduğu görülmüştür. Ayrıca ilçede $1.401 .711 \mathrm{~m}^{2}$ de park yeşil alanı bulunmaktadır. Bu açık yeşil alanın ise $618.320 \mathrm{~m}^{2 \prime}$ sini Mogan Parkı oluşturmaktadır(Gölbaşı Belediyesi Park ve Bahçeler Genel Müdürlüğü 2018 Yılı Faaliyet Raporu).

Çizelge 6. Gölbaşı ilçesinin 2018 Yılı Mevcut Açık Yeşil Alanları (Gölbaşı Belediye Başkanlığı, Park ve Bahçeler Genel Müdürlüğü, 2018 Yılı Faaliyet Raporu’ndan faydalanılarak)

\begin{tabular}{|c|c|}
\hline 2018 YILI AÇIK YEŞiL ALAN DURUMU (AKTIF-PASIF) & YÜZÖLÇÜMÜ $\left(m^{2}\right)$ \\
\hline Ağaçlandırma Alanı & 370.921 \\
\hline Kurumsal Alanlara Ait Yeşil Alanlar & 52.563 \\
\hline Refüj Alanları & 248.367 \\
\hline Mezarlık Alanı & 617.011 \\
\hline Meyve Bahçesi & 45.000 \\
\hline Sevgi Çiçeği Yetiştirme Alanı & 110.982 \\
\hline Belde Yeşil Alanları & 868.660 \\
\hline Toplu Konut Bahçesi & 28.824 \\
\hline Park Alanları-Spor Alanları-Oyun Bahçeleri & 1.401 .711 \\
\hline Eğitim Kurumları Bahçeleri (ilk Öğretim - Orta Öğretim - Lise) & 260.992 \\
\hline Üniversite Kampüs Alanları & 1.183 .000 \\
\hline TOPLAM & 5.185 .231 \\
\hline
\end{tabular}




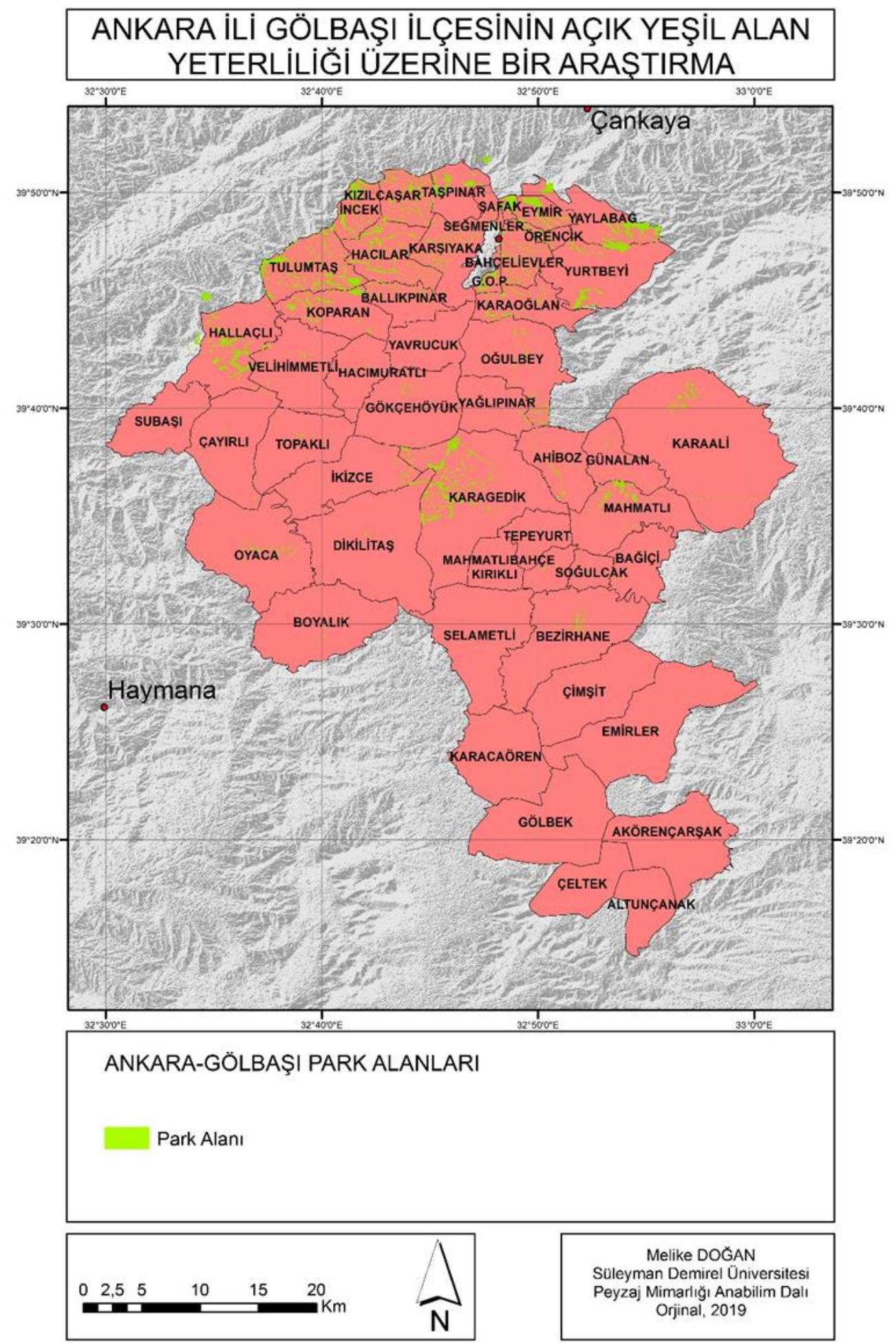

Şekil 4. Gölbaşı ilçesi açık yeşil alanları (Orijinal, 2019)

\subsection{Park alanları ve okul bahçelerinin yeşil alan standartlarına göre değerlendirilmesi}

02.09.1999 tarihli ve 23804 sayılı "İmar Planı Yapılması ve Değişikliklerine Ait Esaslara Dair Yönetmelikte Değişiklik Yapılması Hakkındaki Yönetmelik" ile kişi başın düşen aktif açık yeşil alan standardı $7 \mathrm{~m}^{2} /$ kişi 'den $10 \mathrm{~m}^{2} /$ kişi 'ye çıkartılmıştır. Bu standart ile okul bahçeleri 1,5 $\mathrm{m}^{2} /$ kişi ve mahalle ünitesi düzeyinde park alanı kişi başına $2 \mathrm{~m}^{2} /$ kişi olarak belirlenmiştir.

\subsubsection{Gölbaşı ilçesindeki okul bahçelerinin mevcut durumu ve standartlara uygunluğu}

134.378 nüfuslu Gölbaşı ilçesi 54 mahallede MEB'e bağlı anaokulu, ilkokul, ortaokul ve lise düzeyinde toplamda 53 okula ev sahipliği yapmaktadır. Ankara Valiliği Milli Eğitim Müdürlüğü’nden alınan verilere göre her mahallede anaokulu, ilköğretim, ortaöğretim ve lise eğitimi veren okul bulunmamaktadır. 54 
mahalle içerisinde Şafak Mahallesi, Karagedik Aydın Mahallesi, Gaziosmanpaşa Mahallesi, Eymir Mahallesi, Karşıyaka Mahallesi, Akarsu Mahallesi, Seğmenler Mahallesi ve İncek Mahallesi dışında lise eğitimi veren mahalle bulunmamaktadır. Ayrıca ilçede 5 adet ilköğretim düzeyinde eğitim veren "Birleştirilmiş Köy Okulu" bulunmaktadır. Bunlar; Ahiboz Mahallesi-Ahiboz Illkokulu $\left(4.835 \mathrm{~m}^{2}\right)$, Hacı Hasan Mahallesi- Hacı Hasan Illkokulu $\left(2.500 \mathrm{~m}^{2}\right)$, Topaklı Mahallesi-Topaklı ilkokulu $\left(2.780 \mathrm{~m}^{2}\right)$, Yurtbeyi Mahallesi-Yurtbeyi Illkokulu $\left(3.508 \mathrm{~m}^{2}\right)$, Karaali Mahallesi-Karaali illkokulu (12.200 $\left.\mathrm{m}^{2}\right)^{\prime}$ dur.

54 mahallede ayrı ayrı toplam okul bahçesi alanına bakılarak, kişi başına düşen ortalama okul bahçesi alanı hesaplanmıştır. 19 mahalle (Ahiboz Mahallesi, Bezirhane Mahallesi, Eymir Mahallesi, Gaziosmanpaşa Mahallesi, Gökçehüyük Mahallesi, Hacıhasan Mahallesi, İncek Mahallesi, Karaali Merkez-Karaali Yazlık Mahalleleri, Karagedik Aydın-Karagedik Ercan Mahalleleri, Karşıyaka Mahallesi, Oğulbey Mahallesi, Örencik Mahallesi, Selametli Şehit Emrah Mahallesi, Topaklı Mahallesi, Tulumtaş Mahallesi, Şafak Mahallesi, Yurtbeyi Mahallesi) yeşil alan standartlarına uygun iken, 7 mahalle (Bahçelievler Mahallesi, Hacılar Mahallesi, Kızılcaşar Mahallesi, Oyaca Akarsu-Oyaca Yeşilçam Mahalleleri, Seğmenler Mahallesi, Taşpınar Mahallesi) yeşil alan standartlarına uymamaktadır ve 28 mahallede ise hiç okul bulunmamaktadır (Çizelge 7) (Şekil 5).

Çizelge 7. Gölbaşı ilçesi okul bahçelerinin mevcut durumu

\begin{tabular}{|c|c|c|c|c|}
\hline & Mahalle & Nüfus & $\begin{array}{l}\text { Okul Bahçesi Toplam } \\
\text { Alanı }\left(\mathrm{m}^{2}\right)\end{array}$ & $\begin{array}{c}\text { Kişi Başına Düşen } \\
\text { Okul Bahçesi Alanı } \\
\left(\mathrm{m}^{2} / \mathrm{kişi}\right)\end{array}$ \\
\hline 1 & Ahiboz Mahallesi & 275 & 4.835 & 17,58 \\
\hline 2 & Akörençarşak Mahallesi & 340 & - & - \\
\hline 3 & Altunçanak Mahallesi & 73 & - & - \\
\hline 4 & Bağiçi Mahallesi & 528 & - & - \\
\hline 5 & Bahçelievler Mahallesi & 22.549 & 12.586 & 0,55 \\
\hline 6 & Ballıkpınar Mahallesi & 982 & - & - \\
\hline 7 & Bezirhane Mahallesi & 689 & 7.850 & 11,39 \\
\hline 8 & Boyalık Mahallesi & 421 & - & - \\
\hline 9 & Çayırlı Mahallesi & 221 & - & - \\
\hline 10 & Çeltek Mahallesi & 120 & - & - \\
\hline 11 & Çimşit Mahallesi & 337 & - & - \\
\hline 12 & Dikilitaş Mahallesi & 755 & - & - \\
\hline 13 & Emirler Mahallesi & 1.210 & - & - \\
\hline 14 & Eymir Mahallesi & 25.437 & 55.959 & 2,19 \\
\hline 15 & Gaziosmanpaşa Mahallesi & 7.709 & 12.090 & 1,56 \\
\hline 16 & Gökçehüyük Mahallesi & 963 & 7.250 & 7,52 \\
\hline 17 & Gölbek Mahallesi & 244 & - & - \\
\hline 18 & Günalan Mahallesi & 195 & - & - \\
\hline 19 & Hacıhasan Mahallesi & 554 & 2.500 & 4,51 \\
\hline 20 & Hacılar Mahallesi & 2.379 & 535 & 0,22 \\
\hline 21 & Hacımuratlı Mahallesi & 308 & - & - \\
\hline 22 & Halaçlı Mahallesi & 351 & - & - \\
\hline 23 & íkizce Mahallesi & 337 & - & - \\
\hline 24 & İncek Mahallesi & 4.605 & 12.899 & 2,80 \\
\hline 25 & Karaali Merkez Mahallesi & 410 & \multirow[t]{2}{*}{12.200} & \multirow[t]{2}{*}{16,64} \\
\hline 26 & Karaali Yazlık Mahallesi & 323 & & \\
\hline 27 & Karacaören Mahallesi & 456 & - & - \\
\hline 28 & Karagedik Aydın Mahallesi & 1.280 & \multirow[b]{2}{*}{26.460} & \multirow[t]{2}{*}{10,98} \\
\hline 29 & Karagedik Ercan Mahallesi & 1.128 & & \\
\hline 30 & Karaoğlan Mahallesi & 685 & - & - \\
\hline 31 & Karşıyaka Mahallesi & 12.049 & 33.206 & 2,75 \\
\hline 32 & Kırıklı Mahallesi & 115 & - & - \\
\hline 33 & Kızılcaşar Mahallesi & 4.292 & 4.000 & 0,93 \\
\hline 34 & Koparan Mahallesi & 385 & - & - \\
\hline 35 & Mahmatlı Mahallesi & 355 & - & - \\
\hline 36 & Mahmatlıbahçe Mahallesi & 120 & - & - \\
\hline 37 & Oğulbey Mahallesi & 1.547 & 3.000 & 1,93 \\
\hline 38 & Oyaca Akarsu Mahallesi & 926 & \multirow[t]{2}{*}{2.000} & \multirow[t]{2}{*}{1,14} \\
\hline 39 & Oyaca Yeşilçam Mahallesi & 826 & & \\
\hline
\end{tabular}




\begin{tabular}{|l|l|c|c|c|}
\hline 40 & Örencik Mahallesi & 1.078 & 12.254 & 11,36 \\
\hline 41 & Seğmenler Mahallesi & 18.085 & 15.500 & $\mathbf{0 , 8 5}$ \\
\hline 42 & Selametli Ş.E. Mahallesi & 918 & 3.100 & 3,37 \\
\hline 43 & Soğulcak Mahallesi & 174 & - & - \\
\hline 44 & Subaşı Mahallesi & 265 & - & - \\
\hline 45 & Şafak Mahallesi & 9.953 & 15.920 & $\mathbf{0 , 5 1}$ \\
\hline 46 & Taşpınar Mahallesi & 1.946 & 1.000 & - \\
\hline 47 & Tepeyurt Mahallesi & 237 & - & 4,92 \\
\hline 48 & Topaklı Mahallesi & 564 & 2.780 & 5,30 \\
\hline 49 & Tulumtaş Mahallesi & 1.803 & 9.560 & - \\
\hline 50 & Velihimmetli Mahallesi & 771 & - & - \\
\hline 51 & Yağlıpınar Mahallesi & 337 & - & - \\
\hline 52 & Yavrucuk Mahallesi & 385 & - & - \\
\hline 53 & Yaylabağ Mahallesi & 452 & - & 3,76 \\
\hline 54 & Yurtbeyi Mahallesi & 931 & 3.508 & . \\
\hline
\end{tabular}

Not: Koyu yazılan değerler okul bahçesi açısından yetersizdir. '- 'işareti bulunan mahallelerde okul bahçesi yoktur.

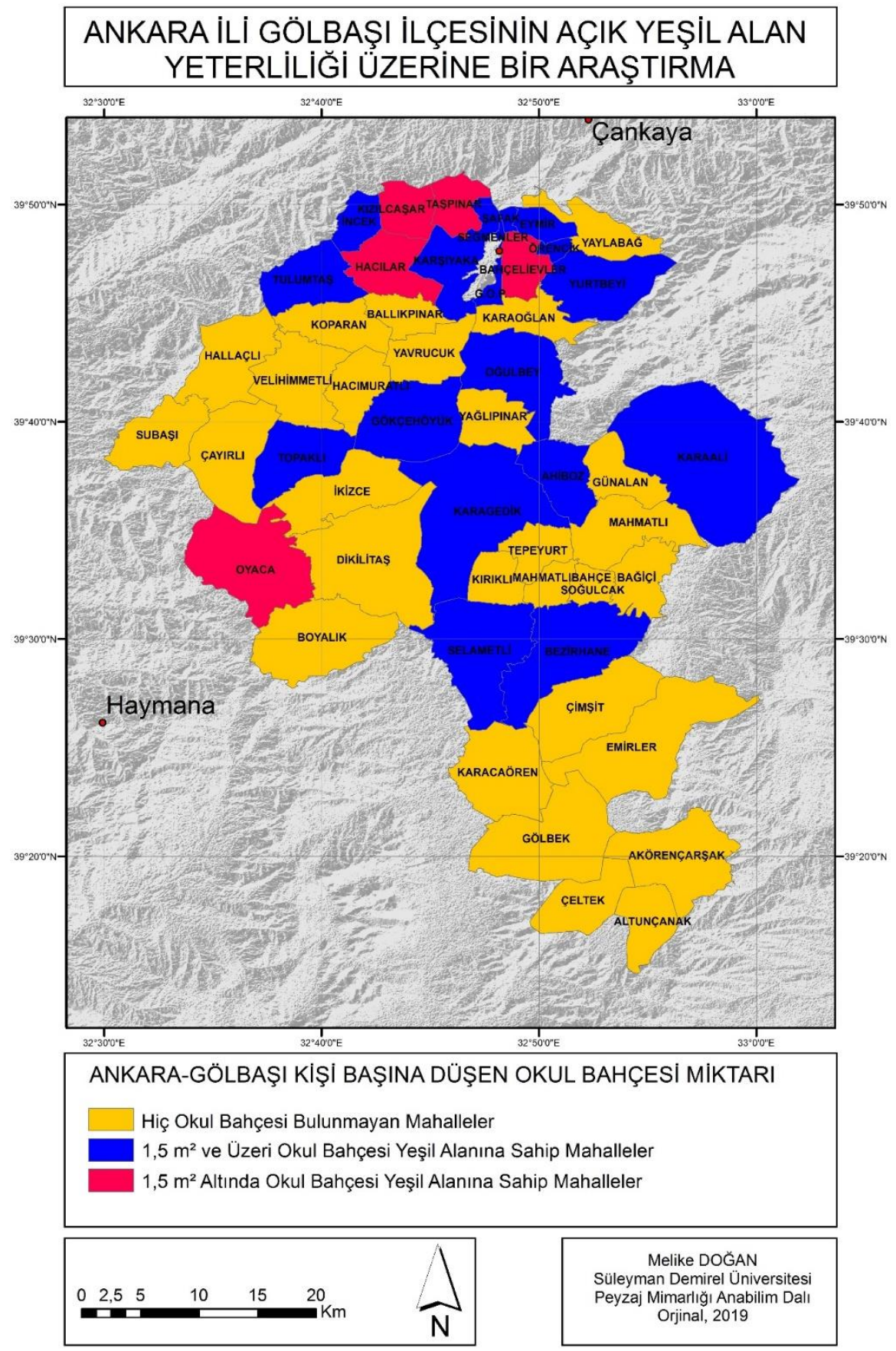

Şekil 5. Gölbaşı ilçesinin okul bahçelerinin standartlara uygunluğu (Orijinal, 2019) 


\subsubsection{Gölbaşı ilçesindeki parkların mevcut durumu ve standartlara uygunluğu}

Gölbaşı ilçesinde 2018 yılı için toplamda kişi başına düşen net açık yeşil alan miktarının 27,84 $\mathrm{m}^{2} /$ kişi ve aktif yeşil alan miktarı ile standartların üzerinde olduğu belirlenirken kişi başına düşen park alanı miktarı her mahalle için yeşil alan standartları göz önüne alınarak hesaplanmıştır. Boyalık Mahallesi ve Oğulbey mahalleleri haricindeki 52 mahallede park bulunmaktadır. 37 mahallede kişi başına düşen park alanı miktarı yeşil alan standartlarına uygun iken, 15 mahallede (Ahiboz Mahallesi, Dikilitaş Mahallesi, Emirler Mahallesi, Gökçehüyük Mahallesi, Karacaören Mahallesi, Karaoğlan Mahallesi, Koparan Mahallesi, Şafak Mahallesi, Taşpınar Mahallesi, Topaklı Mahallesi, Tulumtaş Mahallesi, Yavrucuk Mahallesi, Yaylabağ Mahallesi, Yurtbeyi Mahallesi) uygun değildir (Çizelge 8) (Şekil 6).

Çizelge 8. Gölbaşı ilçesi park alanlarının mevcut durumu

\begin{tabular}{|c|c|c|c|c|}
\hline & Mahalle & Nüfus & $\begin{array}{l}\text { Park Alanları Toplamı } \\
\qquad\left(\mathrm{m}^{2}\right)\end{array}$ & $\begin{array}{l}\text { Kişi Başına Düşen } \\
\text { Park Alanı (m²/kişi) }\end{array}$ \\
\hline 1 & Ahiboz Mahallesi & 275 & 500 & 1,81 \\
\hline 2 & Akörençarşak Mahallesi & 340 & 1.500 & 4,41 \\
\hline 3 & Altunçanak Mahallesi & 73 & 1.100 & 15,07 \\
\hline 4 & Bağiçi Mahallesi & 528 & 1.100 & 2,08 \\
\hline 5 & Bahçelievler Mahallesi & 22.549 & 112.508 & 4,99 \\
\hline 6 & Ballıkpınar Mahallesi & 982 & 14.872 & 15,14 \\
\hline 7 & Bezirhane Mahallesi & 689 & 10.261 & 14,89 \\
\hline 8 & Boyalık Mahallesi & 421 & - & - \\
\hline 9 & Çayırlı Mahallesi & 221 & 1.000 & 4,52 \\
\hline 10 & Çeltek Mahallesi & 120 & 1.350 & 11,25 \\
\hline 11 & Çimşit Mahallesi & 337 & 750 & 2,22 \\
\hline 12 & Dikilitaş Mahallesi & 755 & 900 & 1,19 \\
\hline 13 & Emirler Mahallesi & 1.210 & 1.150 & 0,95 \\
\hline 14 & Eymir Mahallesi & 25.437 & 250.972 & 9,87 \\
\hline 15 & Gaziosmanpaşa Mahallesi & 7.709 & 31.475 & 4,08 \\
\hline 16 & Gökçehüyük Mahallesi & 963 & 400 & 0,41 \\
\hline 17 & Gölbek Mahallesi & 244 & 1.000 & 4,09 \\
\hline 18 & Günalan Mahallesi & 195 & 1.000 & 5,12 \\
\hline 19 & Hacıhasan Mahallesi & 554 & 1.550 & 2,79 \\
\hline 20 & Hacılar Mahallesi & 2.379 & 12.550 & 5,27 \\
\hline 21 & Hacımuratlı Mahallesi & 308 & 800 & 2,59 \\
\hline 22 & Halaçlı Mahallesi & 351 & 760 & 2,16 \\
\hline 23 & İkizce Mahallesi & 337 & 800 & 2,37 \\
\hline 24 & İncek Mahallesi & 4.605 & 24.600 & 5,34 \\
\hline 25 & Karaali Merkez Mahallesi & 410 & \multirow{2}{*}{19.957} & \multirow[t]{2}{*}{27,22} \\
\hline 26 & Karaali Yazlık Mahallesi & 323 & & \\
\hline 27 & Karacaören Mahallesi & 456 & 700 & 1,53 \\
\hline 28 & Karagedik Aydın Mahallesi & 1.280 & \multirow[b]{2}{*}{6.933} & \multirow[b]{2}{*}{2,88} \\
\hline 29 & Karagedik Ercan Mahallesi & 1.128 & & \\
\hline 30 & Karaoğlan Mahallesi & 685 & 700 & 1,02 \\
\hline 31 & Karşıyaka Mahallesi & 12.049 & 65.678 & 5,45 \\
\hline 32 & Kırıklı Mahallesi & 115 & 1.300 & 11,30 \\
\hline 33 & Kızılcaşar Mahallesi & 4.292 & 10.666 & 2,48 \\
\hline 34 & Koparan Mahallesi & 385 & 750 & 1,95 \\
\hline 35 & Mahmatlı Mahallesi & 120 & 1.600 & 13,33 \\
\hline 36 & Mahmatlıbahçe Mahallesi & 355 & 850 & 2,39 \\
\hline 37 & Oğulbey Mahallesi & 1.547 & - & - \\
\hline 38 & Oyaca Akarsu Mahallesi & 926 & \multirow[t]{2}{*}{10.296} & \multirow[t]{2}{*}{5,88} \\
\hline 39 & Oyaca Yeşilçam Mahallesi & 826 & & \\
\hline 40 & Örencik Mahallesi & 1.078 & 1.800 & 1,67 \\
\hline 41 & Seğmenler Mahallesi & 18.085 & 50.567 & 2,79 \\
\hline 42 & Selametli Şehit Emrah Mahallesi & 918 & 7.725 & 8,41 \\
\hline 43 & Soğulcak Mahallesi & 174 & 700 & 4,02 \\
\hline 44 & Subaşı Mahallesi & 265 & 700 & 2,64 \\
\hline 45 & Şafak Mahallesi & 9.953 & 13.533 & 1,39 \\
\hline 46 & Taşpınar Mahallesi & 1.946 & 2.705 & 1,39 \\
\hline 47 & Tepeyurt Mahallesi & 237 & 1.150 & 4,85 \\
\hline
\end{tabular}




\begin{tabular}{|l|l|c|c|c|}
\hline 48 & Topakıı Mahallesi & 564 & 700 & $\mathbf{1 , 2 4}$ \\
\hline 49 & Tulumtaş Mahallesi & 1.803 & 2.888 & $\mathbf{1 , 6 0}$ \\
\hline 50 & Velihimmetli Mahallesi & 771 & 6.700 & 8,69 \\
\hline 51 & Yağlıpınar Mahallesi & 337 & 800 & 2,37 \\
\hline 52 & Yavrucuk Mahallesi & 385 & 700 & $\mathbf{1 , 8 1}$ \\
\hline 53 & Yaylabağ Mahallesi & 452 & 820 & $\mathbf{1 , 8 1}$ \\
\hline 54 & Yurtbeyi Mahallesi & 931 & 1.250 & $\mathbf{1 , 3 4}$ \\
\hline
\end{tabular}

Not: Koyu yazılan değerler park alanı açısından yetersizdir. '-' işareti bulunan mahallelerde park yoktur.

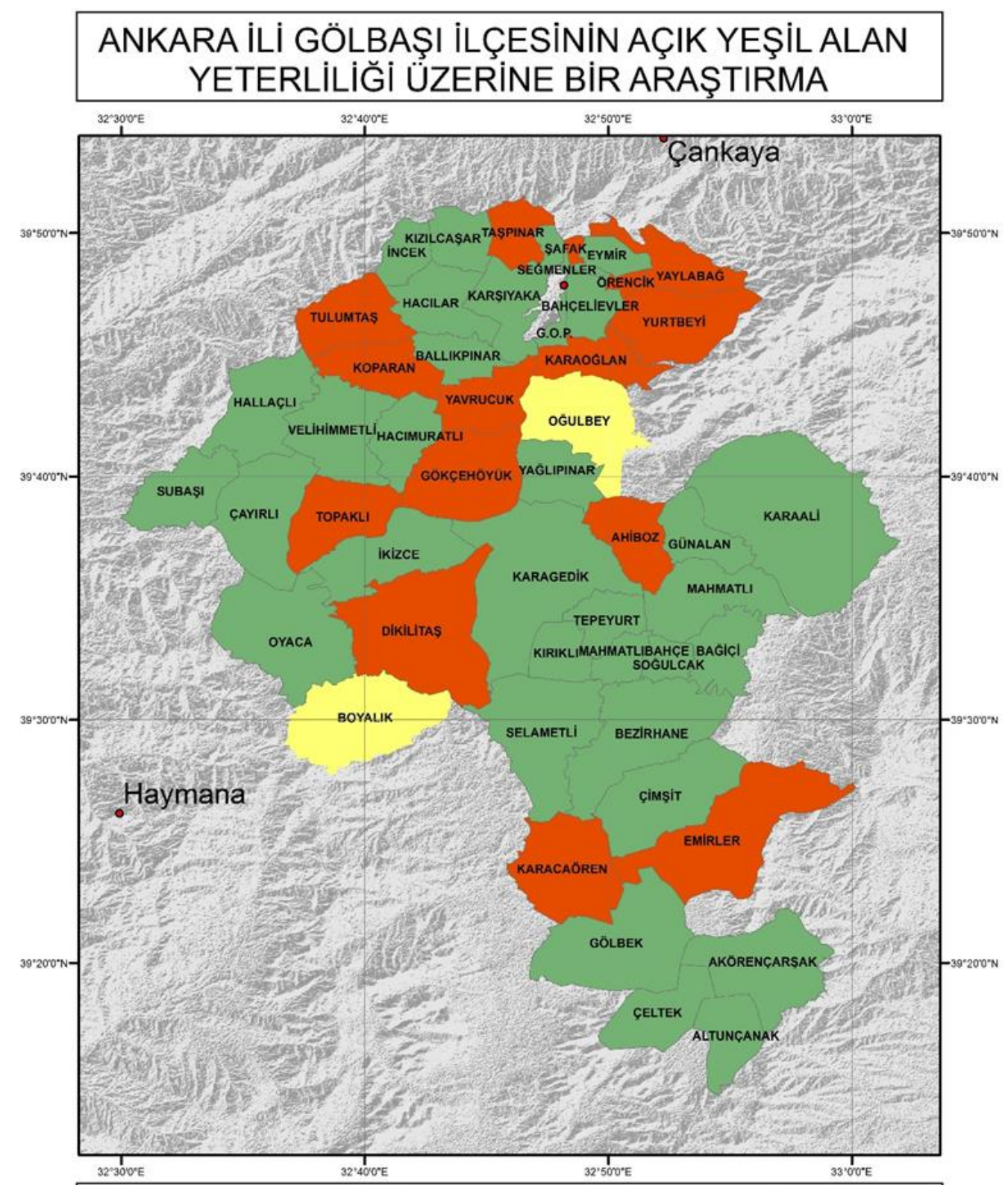

ANKARA-GÖLBAŞI KIŞI BAŞINA DÜŞEN PARK ALANI MIKTARI

Hiç Park Bulunmayan Mahalleler

Kişi Başına $2 \mathrm{~m}^{2}$ ve Üzeri Park Alanı Düşen Mahalleler

Kişi Başına $2 \mathrm{~m}^{2}$ Altında Park Alanı Düşen Mahalleler

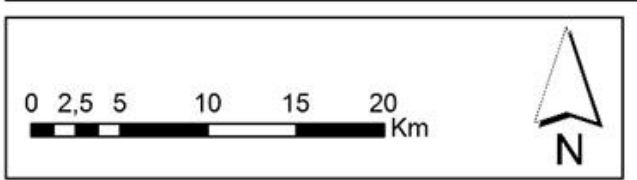

Melike DOGAN

Süleyman Demirel Oniversitesi

Peyzaj Mimarığı Anabilim Dalı

Orjinal, 2019

Şekil 6. Gölbaşı ilçesinin park alanlarının standartlara uygunluğu (Orijinal, 2019) 


\section{Sonuç ve Öneriler}

Kentlerin yoğun kullanımı, çarpık kentleşmenin getirdiği sorunlar, hızlı nüfus artışı gibi olumsuzlukların son yıllarda açık yeşil alanlara duyulan gereksinimi ve ilgiyi arttırdığı görülmüştür. Açık-yeşil alanların, intiyaçlara cevap verebilir nitelikte ve nicelikte olması ve yüksek yaşam kalitesi sunması önem arz etmektedir. Bu sebeple ekonomik ve ekolojik olarak birçok işleve sahip yeşil alanlar belirli standartlara göre planlanmalıdır. Bu standartlar ise imar mevzuatında yer almaktadır.

Bu çalışmada imar mevzuatı dikkate alınarak Ankara ili Gölbaşı ilçesi açık-yeşil alanlarının sahip oldukları niceliksel değerlerin ve belirli standartlara uygunluklarının değerlendirilmesi için çalışılmıştır.

Bu değerlendirmelerden önce alanın doğal ve kültürel özellikleri ortaya konulmuştur. Bu özelliklerin kentleşme ve nüfus üzerinde kısmen etkisi olduğu söylenebilmektedir.

Yapılan yeşil alan envanteri ve incelenen raporlar ile Gölbaşı ilçesinin sahip olduğu net açık yeşil alan miktarı ve aktif yeşil alan miktarı belirlenmiştir. İlçenin sahip olduğu net açık yeşil alanlar; mezarlıklar, refüjler, meyve bahçeleri, ağaçlandırma alanları, imarda yeşil alan olarak ayrılmış alanlar, kamusal yeşil alanlar, parklar, oyun bahçeleri, spor alanları ve konut bahçeleri olarak sınıflandırılmışlardır. Kişi başına düşen net yeşil alan miktarı ve aktif yeşil miktarı hesaplandığında çalışma alanının sahip olduğu yeşil alanların büyük çoğunluğunu park alanlarının oluşturduğu görülmüştür.

Gölbaşı ilçesinin açık-yeşil alan durumunun son 12 yıllık değerlenmesi yapılmış ve son olarak güncel net açık yeşil alan miktarı, aktif yeşil alan miktarı, kişi başına düşen net ve aktif ortalama yeşil alan miktarları belirlenmiş ve kişi başına düşen okul bahçesi alanı ile park alanı Gölbaşı ilçesinin 54 mahallesi baz alınarak ortaya konmuştur.

Değerlendirmesi yapılacak yeşil alanların toplamının nüfusa oranlanması ile yeterlilik değerlendirmesi yapılmış, kişi başına düşen ortalama miktar belirlenmiştir. Bu değerlendirmeler yapılırken güncel imar mevzuatında yer alan yeşil alan standartları göz önüne alınmıştır.

Yeşil alanların, fonksiyonları ya da büyüklükleri farklı olsa da değerlendirildikleri standartlar, imar kanunlarıyla belirlendiği için değişiklik göstermemektedir. Ülkemizde 23804 sayılı "Imar Planı Yapılması ve Değişikliklerine Ait Esaslara Dair Yönetmelik" ile 02.09.1999 tarihinde kişi başına düşen aktif yeşil alan miktarı $10 \mathrm{~m}^{2} /$ kişi olarak belirlenmiştir. Değerlendirmeler bu standarda göre yapılmıştır.

Güncel net açık yeşil alanları ve aktif açık yeşil alanlarının durumuna bakıldığında, 2 durum içinde sırasıyla $38,6 \mathrm{~m}^{2} /$ kişi ve $11,0 \mathrm{~m}^{2} /$ kişi ile standartların üzerinde oldukları görülürken; toplam yeşil alan miktarı 5.185.231 $\mathrm{m}^{2 \prime}$ dir.

Standartların üzerinde yeşil alan miktarına sahip olmasına karşın bu yeşil alanların ilçe içerisindeki dağııımı incelendiğinde; Gölbaşı ilçesinin 54 mahallesinin \% 68 inde park alanları yeşil alan standartlarına uygun iken, \% 28 inde standartların altında kaldığı ve \% 4 lük kısımda ise hiç park olmadığı görülmüştür.

Nüfusun son 10 yıl içerisindeki değişimi göz önüne alındığında her yıl ortalama 5000 kişi artığı gözlenmiştir. Nüfustaki bu artışın sürekliliğine bakılarak park alanlarının, rekreasyon alanlarının, dinlenme ve spor alanlarının, açık yeşil alanların da devamlılı̆ının zorunlu olması gerektiği söylenebilmektedir. Artan nüfusla birlikte bu alanlara duyulan ihtiyacın da arttığı, standartlarla ortaya çıkmıştır. Açık yeşil alanların nüfusa oranlar artırılması, geliştirilmesi ve iyileştirilmesi gerektiği söylenirken bu alanların dağılımındaki farklııklarında göz önüne alınması gerekmektedir.

Okul bahçesi alanına bakıldığında Gölbaşı ilçesinin \% 52'sinde hiç okul olmadığı, \% 35'luk kısmında standartlara uygun $\left(1,5 \mathrm{~m} \mathrm{~m}^{2} /\right.$ kişi ve üzeri) okul alanı bulunduğu ve kalan \% $13^{\prime}$ lik alanın ise standartların altında kaldığı görülmüştür.

Çalışma alanının açık yeşil alanlarının ve bunların dağılımlarının irdelenmesinin yanı sıra ilçe belediyesinden alınan imar planı da detaylı olarak incelenmiştir. İmar planına bakıldığında mevcut yeşil alanların dışında park alanı olarak ayrıımış ancak hiçbir düzenleme yapılmamış alanların miktarının da oldukça fazla olduğu görülmüştür. Gölbaşı ilçesinde park alanı standartlarına uymayan \% 32 'lik kısım düşünüldüğünde imar planlarının takibinin düzenli bir şekilde yapılması ve standartlar göz önüne 
alınarak planlama ve uygulamalar getirilmesi, yeşil alanlar olarak ayrılan alanların uygulamaya dönüştürülmesi gerektiği öngörülmüştür.

İmarda ayrılan yeşil alanların düzenlenmesi ve uygulanması tamamlandığında ilçenin aktif yeşil alan varlığına önemli ölçüde katkıda bulunacağı, yeni, kullanışlı, fonksiyonel rekreasyon alanları sağlayacağı ve yeşil alanların farklılığı azaltacağı düşünülmektedir.

Resmi kurumlara ait yeşil alanlar, kültür merkezlerinin bahçeleri gibi alanlar, ilçede halkın kullandığı, değerlendirdiği önemli alanlardır ve ilçede önemli bir alanı kapsamaktadırlar. Park alanının kişi başına düşen miktarının çok düşük olduğu kimi mahallelerde, kültür merkezi bahçesinin park alanından fazla olduğu görülmüştür. Bütün bunlar dikkate alındığında, güzel bir şekilde düzenliklerinde açık yeşil alanlara önemli katkılar sağlayacakları düşünülmektedir.

Eğitim kurumu alanlarının ise ilçede ilköğretim, orta öğretim ve lise bahçeleri olmak üzere toplam $260.992 \mathrm{~m}^{2}$ alan ve üniversite kampüs alanları olmak üzere $1.183 .000 \mathrm{~m}^{2}$ alan ile ilçede oldukça önemli bir alanı kapladığı görülmüştür. Genç- çocuk nüfusun kullandığı bu alanların ihtiyaca cevap verebilir, her türlü olanağı sağlayan alanlar olarak planlanması ve düzenlenmesi, kentin açık yeşil alanlarına önemli katkılarda bulunacaktır. Spor alanı, oyun alanı, rekreasyon alanı, dinlenme ve eğlence alanları gibi birçok aktivite için uygun alanı sağlaması gereken eğitim kurumları bahçeleri Gölbaşı ilçesi için dağııım ve yeterlilik bakımından yetersizdir. Ayrıca ilçede bulunan okul bahçelerinde sert zemin ağırlıkta olması da bu alanların fonksiyonlarından faydalanmayı kısıtlayan etmenlerdir. Araştırma alanında ki eğitim kurumu bahçelerinin dağılımında ki eşitsizliğin giderilmesi ve yeşil dokusunun artırılması için yapılacak çalışmalar ile ilçe yeşil alanlarına önemli katkılar sağlanabileceği düşünülmektedir. Ayrıca kullanıcılarda yeşil alanların varlığının önemi, işlevleri ve faydaları hakkında gerekli bilinç oluşturulmalı ve bunun sağlanması için okul bahçelerinde özellikle yeşil alan dokusu ayrılmasının faydalı olabileceği düşünülmektedir. Üniversite kampüs alanları; 54 mahalleli Gölbaşı ilçesinde, Bahçelievler Mahallesi'nde Ankara ve Gazi Üniversitesi ile Kızılcaşar Mahallesi'nde Atılım ve Ufuk Üniversitesi olarak 2 mahalleye yayılmıştır ve ilçe için önemli miktarda dış mekân kampüs alanı ve bahçe alanına sahiplerdir. Bu alanların da hem fonksiyonel hem estetik birçok amaca hizmet eder ve intiyaçlara cevap verebilir biçimde tasarlanmış olması ilçe için ve bu alanları kullanan genç nüfus için önem arz etmektedir. Öğrencilerin veya eğitimcilerin günlerinin büyük çoğunluğunu bu alanlarda geçirdiği düşünülerek planlanmaları ve tasarlanmalarının ise faydalanmayı ve memnuniyeti artıracağı düşülmektedir.

İlçede toplam $370.921 \mathrm{~m}^{2}$ ağaçlandırma alanı bulunmaktadır. Ağaçlandırma alanları aktif yeşil alan olmamakla birlikte ilçe için önemli bir yeşil alanı oluşturmaktadırlar. Ancak yalnızca 14 alanda ağaçlandırma alanı bulunmakta ve homojen dağılım söz konusu olmamaktadır. Bu alanların korunması ve artırılması için çalışmalar yapılmalıdır.

Araştırma alanında ayrıca $248.367 \mathrm{~m}^{2}$ refüj yeşil alanı bulunmaktadır. Refüj yeşil alanları pasif yeşil alan olmalarına rağmen, yayalar için ve trafiği yönlendiren, ilçe giriş çıkışlarını üçgen veya yuvarlak büyük yeşil akslarla düzenleyen önemli alanlardır. Bu sebeple yapılacak düzenlemelerle refüj alanlarının varlığı artırılmalıdır.

Tüm değerlendirmelere sonucunda Gölbaşı ilçesi yeşil alanlarının standartların üzerinde olduğu ancak bu yeşil alanların dağılımında ki eşitsizliğin giderilmesi için; ilçenin gelecekte ki nüfus planlaması da dikkate alınarak, yeşil alanların büyüme hızının nüfusa paralel olarak gelişim gösterdiği bir planlama yapılması gerektiği, ancak böylelikle yeşil alanların ilçe içerisinde homojen dağııım gösterdiği sağlıklı çevrelerin oluşumunun mümkün olduğu düşünülmektedir.

\section{Kaynaklar}

Aksoy, Y. (2001). İstanbul Kenti Yeşil Alan Durumunun İrdelenmesi. İstanbul Teknik Üniversitesi, Fen Bilimleri Enstitüsü, Doktora Tezi, 233s, İstanbul.

Aksoy, Y. (2014). Türkiye'de Yeşil Alanlarla İlgili Yasal Düzenlemeler, İstanbul Ticaret Üniversitesi, Fen Bilimleri Dergisi, 26(2), 1-20.

Çelik, G. (2013). Manavgat Merkez Illçesi Yeşil Alanlarının İrdelenmesi. Bahçeşehir Üniversitesi, Fen Bilimleri Enstitüsü, Yüksek Lisans Tezi, 178s., İstanbul. 
Çulha, K. (2013). Kırklareli Kent Merkezi Açık Yeşil Alanlarının Nitelik ve Nicelik Açısından İrdelenmesi. Trakya Üniversitesi, Fen Bilimleri Enstitüsü, Yüksek Lisans Tezi, 143s., Edirne.

Döllük, G. (2005). Yayalaştırılmış Sokakların Kent Peyzajına Katkısı. İstanbul Teknik Üniversitesi, Fen Bilimleri Enstitüsü, Yüksek Lisans Tezi, 287s., İstanbul.

Gölbaşı Belediye Başkanlığı, Park ve Bahçeler Genel Müdürlüğü, 2007, 2008, 2009, 2010, 2011, 2012, 2013, 2014, 2015, 2016, 2017, 2018 Yılı Faaliyet Raporları

Gül, A., Küçük, V. (2001). Kentsel Açık-Yeşil Alanlar ve Isparta Kenti Örneğinde İrdelenmesi. Süleyman Demirel Üniversitesi, Orman Fakültesi Dergisi, A(2), 27-48.

Özcan, K. (2000). Kırklareli Kenti Mevcut Alan Kullanım Kararları ve Açık- Yeşil Alan Verileri Değerlendirilmesi Üzerine Bir Araştırma. Ankara Üniversitesi, Fen Bilimleri Enstitüsü, Yüksek Lisans Tezi, Ankara.

Özdindar, A. (2015). Çorum Kent Merkezindeki Yeşil Alanların Nicelik ve Nitelik Açısından Değerlendirilmesi. İstanbul Teknik Üniversitesi, Fen Bilimleri Enstitüsü, Yüksek Lisans Tezi, İstanbul.

Pamay, B. (1978). Kentsel Peyzaj Planlaması, İstanbul Üniversitesi, Orman Fakültesi Yayını. İstanbul

Şahin, Ş., Barış, M.E. (1998). Kentsel Doku İçerisinde Açık ve Yeşil Alan Standardını Belirleyen Etmenler, T.M.M.O.B Peyzaj Mimarlığı Dergisi Sayı: 6, İstanbul

URL-1. TUiK 2019, Adrese Dayalı Nüfus Kayıt Sistemi. Erişim Tarihi:22.02.2019, https://biruni.tuik.gov.tr/medas/?kn=95\&locale=tr 